\title{
Um caso de sinovite vilonodular do ombro em adolescente: diagnóstico por imagem e anatomopatológico
}

\author{
A case of villonodular synovitis of the shoulder in an \\ adolescent: imaging and pathologic diagnosis
}

Beatriz Lavras Costallat ${ }^{(1)}$, Suelen Montagner ${ }^{(1)}$, Eliane Maria Ingrid Amstalden ${ }^{(2)}$, Daniel Miranda Ferreira ${ }^{(3)}$, Américo Zoppi Filho $^{(4)}$, Lilian Tereza Lavras Costallat ${ }^{(5)}$

\section{RESUMO}

Em quadros de monoartrite crônica devem ser investigadas doenças inflamatórias como a artrite reumatoide (AR), doenças infecciosas como a tuberculose e outras doenças que causem espessamento sinovial e derrame articular como sinovite vilonodular pigmentada (SVNP), hemangioma sinovial, osteocondromatose sinovial e lipoma arborescente sinovial. Relatamos o caso de uma jovem paciente com quadro de monoartrite em ombro, cujo exame por imagem mostrou sinovite e cujo exame histopatológico obtido através de artroscopia com biópsia revelou tratar-se de SVNP. Relato do caso: J C M, 15 anos, sexo feminino, branca, estudante, foi encaminhada ao reumatologista com hipótese diagnóstica de artrite idiopática juvenil (AIJ) pauciarticular. Apresentava, há um ano, dor no ombro D, que melhorava com o uso de anti-inflamatório não-esteroidal (AINE) em dois dias. Teve nesse período de cinco a seis destes episódios que duravam poucos dias. Negava outras queixas articulares ou sistêmicas. Trazia exames normais ou negativos: hemograma, VHS, proteína $\mathrm{C}$ reativa, fator reumatoide, sedimento de urina. O FAN era positivo $1 / 80$, pontilhado fino. Trazia Ressonância Magnética do ombro indicativa de sinovite glenoumeral com derrame articular com conteúdo expansivo de tecidos moles na bursa subescapular, segundo o laudo, podendo corresponder a pannus. Como história e exame físico não eram compatíveis com AIJ, foi realizada outra RM que mostrou aumento da lesão já descrita. Foi então encaminhada à

\begin{abstract}
Chronic monoarthritis demand an investigation of inflammatory diseases, such as rheumatoid arthritis (RA), infectious diseases like tuberculosis; and other diseases that cause synovitis and joint effusion, such as pigmented villonodular synovitis (PVNS), synovial hemangioma, synovial osteochondromatosis and arborescence lipoma. We report the case of a young patient with chronic right shoulder monoarthritis, who's magnetic resonance imaging (MRI) showed synovitis. Arthroscopy was performed and the biopsy revealed PVNS. Case report: JC M, 15 years-old, female, Caucasian, student. She was sent to a Rheumatologist along with a diagnosis of juvenile idiopathic arthritis (JIA). The patient presented, for one year, a mild pain of insidious onset in her right shoulder, with relief of the symptoms in two days under nonsteroidal anti-inflammatory therapy (NSAIDs). During this year, the patient presented five or six episodes of pain with the same characteristics. No other signs and symptoms were related. The following tests showed normal or negative results:complete blood count, ESR, C-reactive protein, rheumatoid factor and urinalysis. The antinuclear antibody (ANA) was 1/80 speckled pattern. The MRI of the shoulder showed glenohumeral synovitis with joint effusion and soft tissue swelling in the subscapular bursa, which could correspond to pannus. As the medical history and physical examination were not compatible to JIA, a second MRI was performed, which showed an increase of the synovitis. The patient was submitted to an arthroscopy
\end{abstract}

Recebido em (Received on) 30/9/2008. Aprovado (Approved), após revisão, em 14/11/08. Declaramos a inexistência de conflitos de interesse (We declare no conflict of interest).

1. Graduada em Medicina - Faculdade de Ciências Médicas - Pontifícia Universidade Católica de São Paulo - PUC-SP

1. Graduate in Medicine - Faculdade de Ciências Médicas - Pontifícia Universidade Católica de São Paulo - PUC-SP

2. Professora Assistente, Doutora do Departamento de Anatomia Patológica - Faculdade de Ciências Médicas - UNICAMP

2. Assistant Professor, Doctor of Department of Anatomic Pathology - Faculdade de Ciências Médicas - UNICAMP

3. Professor Assistente, Doutor do Departamento de Radiologia - Faculdade de Ciências Médicas - UNICAMP

3. Assistant Professor, Doctor of Department of Radiology - Faculdade de Ciências Médicas - UNICAMP

4. Professor Voluntário do Departamento de Ortopedia e Traumatologia - Faculdade de Ciências Médicas - UNICAMP

4. Volunteer Professor Department of Orthopedics and Traumatology - Faculdade de Ciências Médicas - UNICAMP

5. Professora Titular de Reumatologia do Departamento de Clinica Médica - Faculdade de Ciências Médicas - UNICAMP

5. Full Professor of Rheumatology, Department of Internal Medicine - Faculdade de Ciências Médicas - UNICAMP

Endereço para correspondência (Correspondence to): Beatriz Lavras Costallat. Rua Ezequiel Magalhães, 26 Jardim das Paineiras, Condomínio Iguatemi.

Campinas, SP, CEP (Zip Code): 13092-522. E-mail: biacostallat@hotmail.com. 
artroscopia para biópsia, que revelou SVNP. Durante o procedimento, foi realizada sinovectomia, e uma nova RM feita após nove meses mostrou ausência de sinovite. A SVNP do ombro é incomum e a sinovectomia foi curativa nesse caso.

Palavras-chave: monoartrite, sinovite vilonodular pigmentada, ombro, sinovite.

\section{INTRODUÇÃO}

O envolvimento monoarticular crônico pode ocorrer em doenças inflamatórias como a artrite reumatoide (AR) e doenças infecciosas como a tuberculose. Outras entidades podem comprometer uma única articulação, como as patologias de origem mecânica e aquelas que cursam com derrame articular e espessamento sinovial, como a sinovite vilonodular pigmentada (SVNP), o hemangioma sinovial, a osteocondromatose sinovial e o lipoma arborescente sinovial. ${ }^{1-3}$

Nesses casos, a história e o exame físico do paciente são fundamentais para nortear o diagnóstico. Nos casos de AR, o envolvimento do ombro como única articulação acometida é muito incomum.

Relatamos o caso de uma paciente de 15 anos de idade com quadro de monoartrite em ombro e FAN positivo cuja investigação diagnóstica por imagem e biópsia através de artroscopia revelou tratar-se de sinovite vilonodular. A sinovite vilonodular foi descrita pela primeira vez em 1852, por Chassaignac, ${ }^{4}$ como uma lesão nodular com origem em bainhas tendinosas flexoras dos dedos, e em 1864, Simon ${ }^{5}$ observou a ocorrência da forma localizada dessa doença no joelho, tendo, em 1909, sido Moser ${ }^{6}$ o primeiro a relatar a sua forma difusa. Só em 1941, Jaffe et al. ${ }^{7}$ propuseram o termo sinovite vilonodular pigmentada em estudo de 20 casos; atualmente, a nomenclatura proposta por Granowitz et al. é a mais usada. ${ }^{8}$

\section{RELATO DO CASO}

J.C.M., 15 anos, sexo feminino, branca, estudante, apresentava há um ano história de dor no ombro direito (D), ritmo inflamatório, que melhorava com o uso de anti-inflamatório não-esteroidal (AINE) e que tinha duração de dois a três dias. Teve, nesse período, de cinco a seis episódios de dores na mesma articulação, sempre melhorando com o uso de AINE. Negava outras queixas articulares ou sistêmicas. Referia lesões de pele, eritematosas, por todo o tronco e braços. Fora encaminhada ao dermatologista, que diagnosticou farmacodermia por AINE. Trazia exames normais ou negativos: hemograma, with biopsy and the histopathological examination showed PVNS. A complete synovectomy was performed and a new MRI, nine months later, showed no synovitis. PVNS of the shoulder is uncommon, and synovectomy was curative in this case.

Keywords: monoarthritis, pigmented villonodular synovitis, shoulder, synovitis.

VHS, proteína $\mathrm{C}$ reativa, fator reumatoide, com exceção do FAN, positivo $1 / 80$ pontilhado fino. Trazia ressonância magnética (RM) do ombro evidenciando sinovite glenoumeral com derrame articular com conteúdo expansivo de tecidos moles na bursa subescapular e no recesso axilar, segundo laudo radiológico, podendo corresponder a pannus e sugerindo a possibilidade de doença autoimune (artrite idiopática juvenil, AIJ) (Figuras 1A e 1B).

Com esta hipótese de AIJ foi encaminhada ao reumatologista. No entanto, o exame físico não revelava artrite em outras articulações e os movimentos do ombro D eram normais com um pouco de dor à movimentação. Como a história e o exame físico não eram compatíveis com AIJ e a paciente mantinha a mesma queixa, foi realizada outra RM, que mostrou piora da sinovite já descrita em ombro D (Figuras 2A e 2B).

Foi então encaminhada ao ortopedista para realização de artroscopia com biópsia sinovial, que revelou SVNP (Figuras 3A, 3B, 3C).

Durante o procedimento de artroscopia, a paciente foi submetida a sinovectomia, e o controle da RM feito após nove meses mostrava ausência de sinovite (Figura 4).

\section{DISCUSSÃO}

Essa jovem paciente apresentou leve dor em ombro com discreta limitação de movimento, e a primeira avaliação por imagem mostrou espessamento da sinóvia sugestivo de pannus, motivo pelo qual foi pesquisada a presença do fator reumatoide, que era negativo, e o FAN que era positivo 1/80, buscando confirmar o diagnóstico de AIJ. Não havia qualquer outra evidência clinica ou laboratorial de AIJ e a característica da dor não era de doença inflamatória. O FAN pode ser justificado pela frequência na população sem doença autoimune; nesses casos, o padrão mais encontrado é o pontilhado fino denso, como observado nessa paciente. Outro fato que chamava a atenção do clínico naquela ocasião era a presença de lesões eritematosas que, associadas ao FAN positivo, fez suspeitar de doença autoimune, mas a avaliação dermatológica afastou essa hipótese por tratar-se de farmacodermia. 
ficados dentro da articulação. O lipoma sinovial é uma massa intra-articular isolada; tem intensidade de sinal semelhante à da gordura em todas as sequências, tal como o lipoma arborescente, mas pode distinguir-se pela sua forma redonda ou oval e pela ausência de proliferação sinovial. O lipoma arborescente é uma rara doença intra-articular, de etiologia desconhecida, que consiste em infiltração difusa da membrana sinovial por gordura. O conteúdo lipomatoso da lesão é bem caracterizado na RM ou na tomografia computadorizada. O sarcoma sinovial apresenta extensão extra-articular, a calcificação e a invasão óssea, aspectos estes não encontrados na SVNP. ${ }^{36-39}$

$\mathrm{O}$ tratamento consiste na sinovectomia, que tem muito bom resultado e pouca recorrência em se tratando da forma nodular. Já a forma difusa pode ter alta recorrência. Os pacientes não tratados adequadamente podem evoluir para destruição articular e a artroplastia pode ser a solução nesses casos. ${ }^{41-45}$

Essa paciente teve excelente resposta à sinovectomia, como demonstra a RM realizada nove meses após.

\section{Villonodular synovitis of the shoulder in an adolescent: imaging and pathologic diagnosis}

\section{INTRODUCTION}

Chronic monoarticular involvement can occur in inflammatory diseases such as rheumatoid arthritis (RA) and infectious diseases like tuberculosis. Other entities can compromise a single joint, like the mechanical originated disorders and those which presents with articular effusion and synovial thickening, like pigmented villonodular synovitis (PVNS), synovial hemangioma, synovial osteochondromatosis and synovial arborescence lipoma. ${ }^{1-3}$

In these cases, the history and the physical exam of the patient are fundamental to guide the diagnosis. In cases of RA, the involvement of the shoulder as the only involved joint is very uncommon.

We report the case of a 15 years old patient with a shoulder monoarthritis and a positive antinuclear antibody (ANA), whose diagnostic investigation by imaging and biopsy through an arthroscopy revealed to be villonodular synovitis. The PVNS was described for the first time in 1852 , by Chassaignac, ${ }^{4}$ as a nodular lesion with origin in flexor tendinous sheath of the fingers, and in 1864, Simon ${ }^{5}$ observed the occurrence of the localized form of this disease in the knee, being Moser $^{6}$, in 1909, the first to relate its diffuse form. Only in 1941, Jaffe et al. ${ }^{7}$ proposed the term pigmented villonodular synovitis, in a study of 20 cases; today the nomenclature proposed by Granowitz et al. is the most used. ${ }^{8}$

\section{CASE REPORT}

J.C.M., 15 years old, female, Caucasian, student. She presented, for a year, a history of pain in the right shoulder (R) with inflammatory caractheristics, which got better with the use of nonsteroidal anti-inflammatory (NSAID) and lasted for 2 to 3 days. She had in this period 5 to 6 episodes of pain in the same joint, always improving with the use of NSAID. Other complaints, articular or systemic, were denied. The patient referred erythematous skin lesions all over the trunk and arms. She was referred to the dermatologist that diagnosed pharmacodermia by NSAID. The following tests were normal or negative: complete blood count, ESR, C-reactive protein, rheumatoid factor. ANA were positive $1 / 80$, fine speckled. The magnetic resonance imaging (MRI) of the shoulder showed glenoumeral synovitis with joint effusion and expansive contents of soft tissues in the subscapular bursa and in the axillar recess, according to radiological report, could correspond to pannus and suggesting the possibility of an autoimmune disease (juvenile idiopathic arthritis- JIA) (Figures 1A e 1B).

The patient was referred to the rheumatologist with a JIA hypothesis. However, the physical examination revealed no arthritis in other joints and the movements of the right shoulder were normal with discrete pain. As the history and the physical exam were not compatible with JIA, and since the patient kept the same complaint, another MRI was performed, showing an increase of the synovitis already described in the right shoulder. (Figures 2A and 2B).

The patient was then referred to the orthopedic surgeon to perform an arthroscopy with synovial biopsy, which revealed pigmented villonodular synovitis (Figures 3A, 3B, 3C).

During the arthroscopy procedure, the patient underwent a synovectomy, and the control MRI done after nine months showed absence of synovitis (Figure 4).

\section{DISCUSSION}

This young patient presented a mild pain in the shoulder with a discrete limitation of movement, and the first evaluation by imaging showed synovial thickening suggestive of pannus. In an attempt to confirm the JIA diagnosis, the patient was checked for the presence of rheumatoid factor, which was 


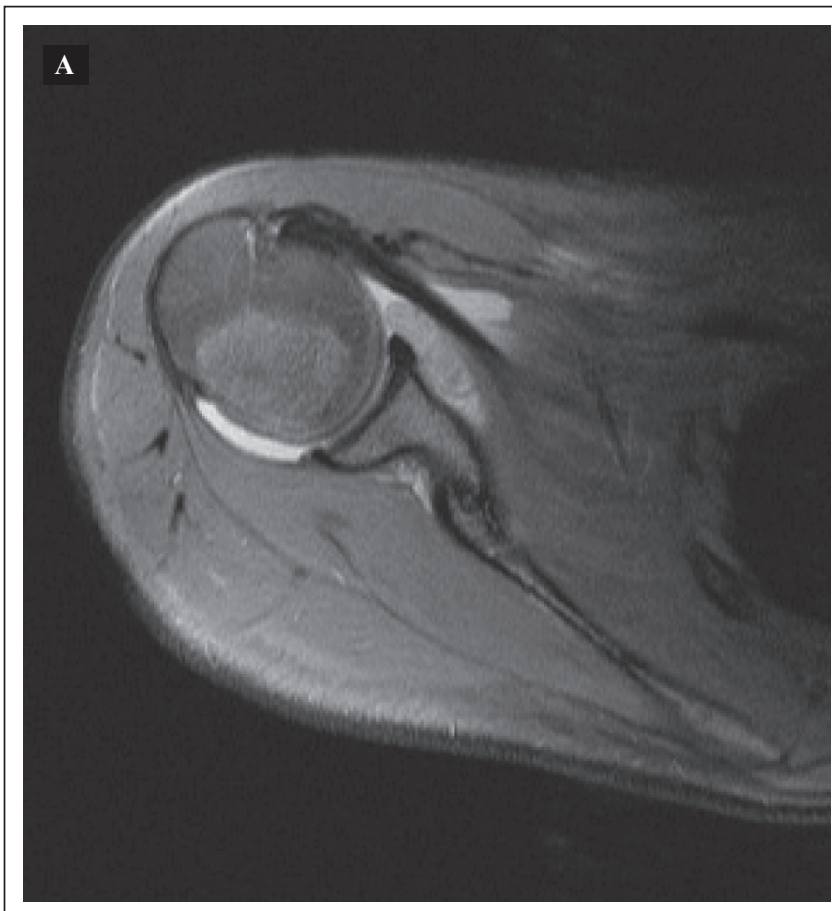

B (postgadolinium)

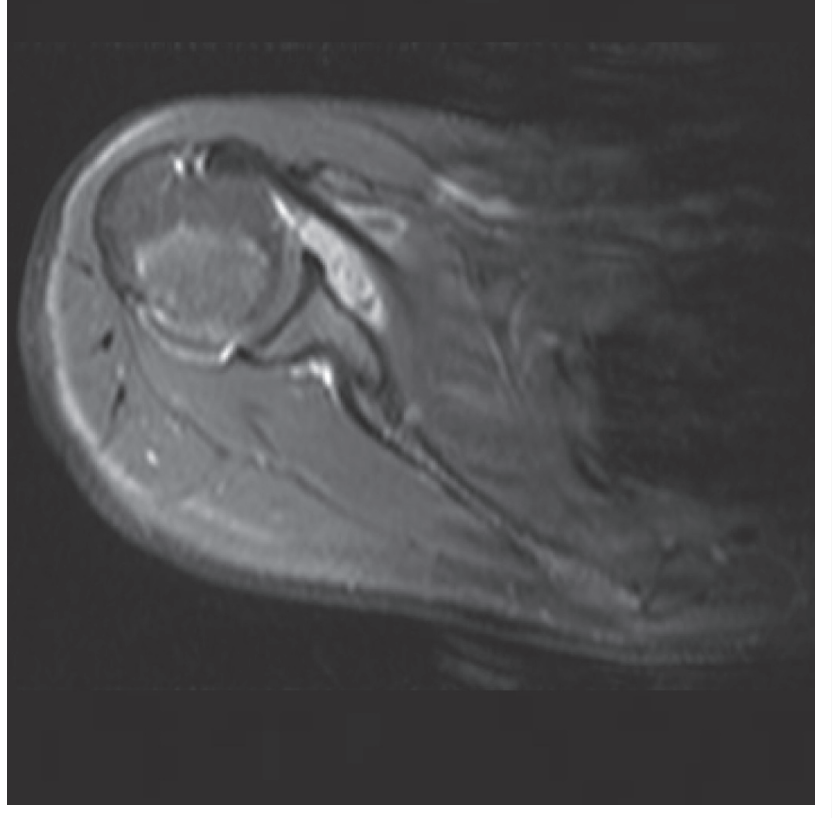

Figure 1. MRI of right shoulder demonstrate discrete diffuse synovial thickening, hypercaptant by contrast, with moderated effusion in the glenohumeral articular space. Presence of soft tissues mass, of oval aspect, compromising the subscapular bursa and the axillar recess regions. Images in T2-weighted sequences with fat saturation with low intensity signal, with small granules in between. Signal indicative of glenohumeral synovitis with joint effusion. Expansive content of soft tissues in the subscapular bursa and in the axillar recess, which could correspond to tissual hypertrophy of the synovia (pannus).

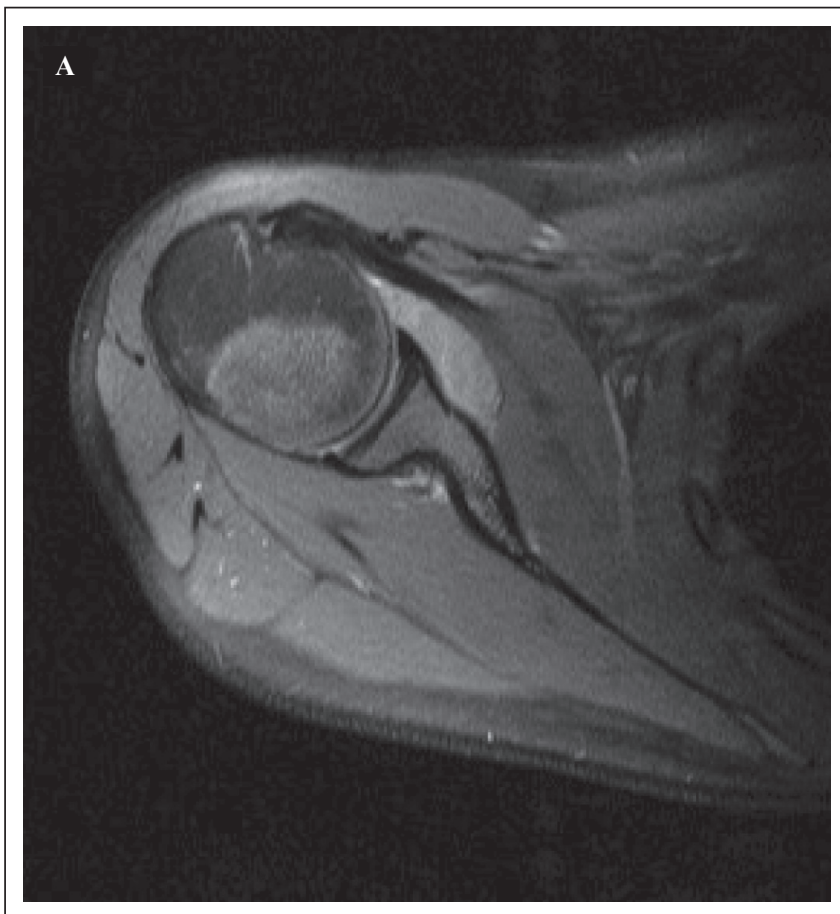

B (postgadolinium)

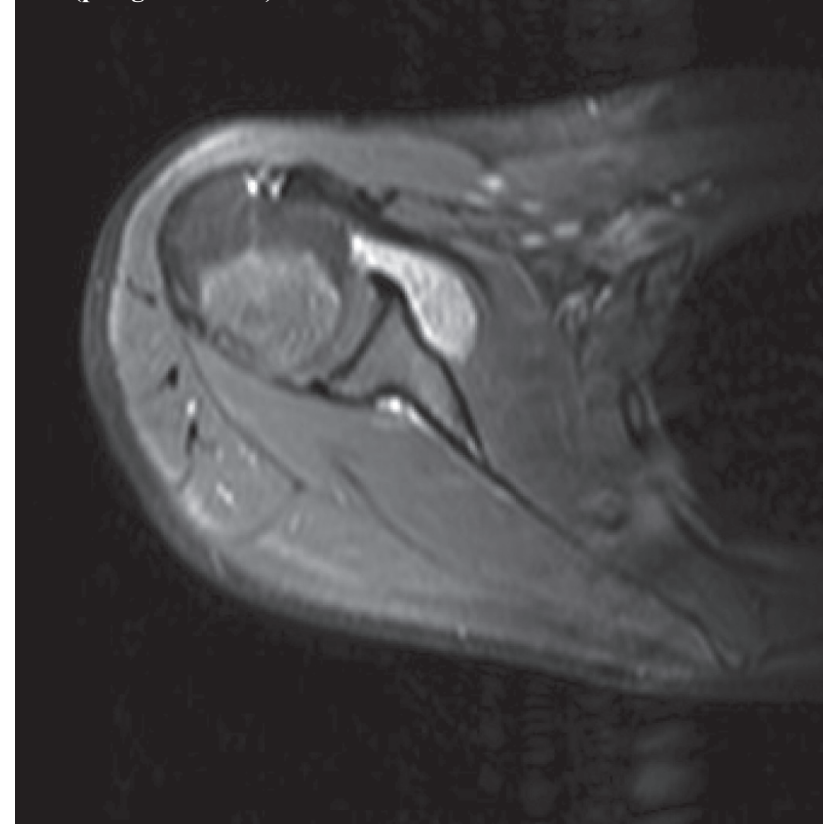

Figure 2. MRI of right shoulder demonstrate persistence of soft tissues mass, of oval aspect, compromising the subscapular bursa and the axillar recess, with volumetric increase when compared to a previous exam. T2-weighted image with fat saturation shows low signal intensity with small granules in between (of riziform aspect), and with isosignal to musculature in T1-weighted image. After contrast administration shows marked enhancement. 


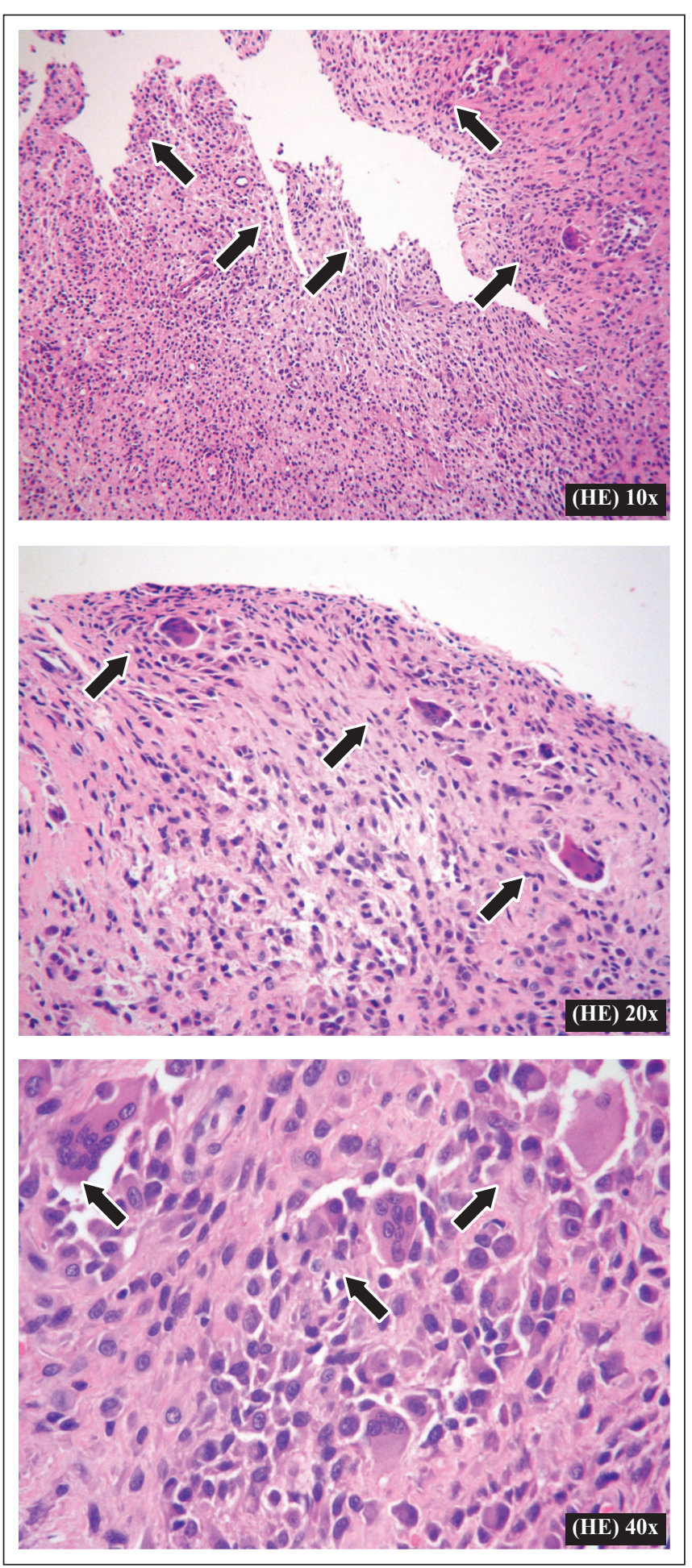

Figures 3. Pigmented villonodular synovitis: Nodular and villous proliferation (arrowheads) which projects itself in the synovial space. Constituted by round and oval shaped cells without nuclear atypicalities, having in between, giant multinuclear cells, sparse or forming small groupings (arrows) over fibroconnective stroma with more colagenated areas.

$\mathrm{HE}=$ Hematoxilin-Eosin

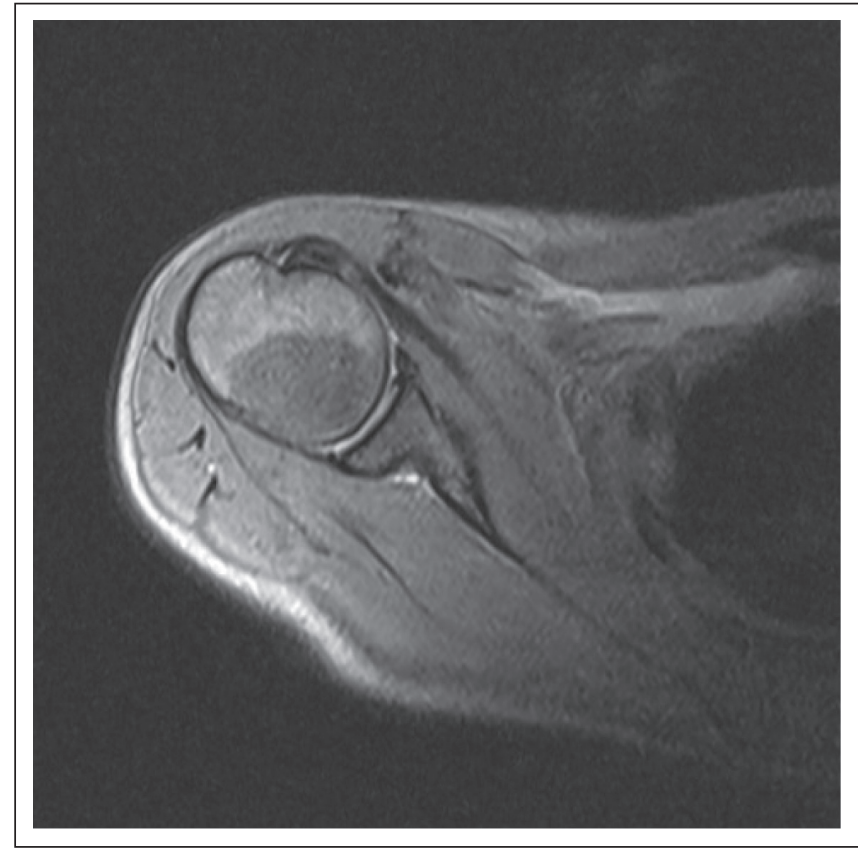

Figure 4: MRI of right shoulder with no evidence of intra-articular effusion or in the synovial prolongment, as well as in the shoulder bursa. There is no evidence of synovitis or joint effusion.

negative, and ANA, which was positive (1/80). There wasn't any other clinical or laboratorial evidence of JIA and the characteristic of the pain wasn't that of an inflammatory disease. The ANA can be justified by the frequency in the population without autoimmune disease; in these cases the most frequent pattern is the dense fine speckled, as observed in this patient. Another fact that drew the attention of the clinician at that occasion was the presence of an erythematous lesion, which associated with the positive ANA raised the suspicion of an autoimmune disease, but the dermatologic evaluation rejected this hypothesis for being a drug eruption.

A second MRI revealed that there was a deterioration of the synovitis after seven months, but there wasn't any suggestive evidence, either clinical or laboratorial, of other disorder. An arthroscopy was then performed for diagnostic elucidation and a complete synovectomy was performed during the procedure. The histopathology revealed pigmented villonodular synovitis (PVNS).

The PVNS is a rare disease, estimated in 1,8 cases/year by million of people. The intra-articular lesions appears in two forms: localized and diffuse. Giant cell tumors of the tendon sheath and villonodular bursitis are related lesions, generally extra-articular, and can be considered as an extra-articular extension of the villonodular synovitis. The PVNS is of an 
unknown etiology and is characterized by hyperplasia of synovial villosities in joints and tendinous sheaths, with accentuated proliferation of the stroma cells, with great quantity of hemosiderotic pigment intra and extracellular and multinucleated giant cells, as observed in this patient. The disease is observed in patients between 20 and 50 years old, more in the male gender, its beginning is gradual, with intermittent pain, associated with hemorrhagic joint effusions and limitation of the articular amplitude. In this patient, the symptoms had lasted around a year, but there wasn't limitation of movement and the pain was fairly discrete. ${ }^{9-19}$

PVNS is a monoarticular and progressive disease, affecting large joints, with the knee compromised in $80 \%$ of the cases in the diffuse form, followed by the coxofemoral and ankles and, more rarely in other, joints. The shoulder, as occurred in the present case, is not frequently involved; there are a few more than 30 cases of villonodular synovitis in the shoulder published in English and French literatures, with the same age distribution already referred. ${ }^{20-35}$

The pathogenesis of this lesion is unknown, being attributed to the reaction to chronic trauma with repeated hemorrhages, or of inflammatory origin, to a local alteration in the metabolism of the lipids, leading to an accumulation of them in the interior of the phagocytes and traumatic secondary alteration or even to a benign neoplastic process, being this last the most probable hypothesis, even though, despite of its aggressive local characteristic, it has not been documented a case of malign transformation or metastasis. In the case of this young patient, the only factor to be considered is the many years of ballet practice, which could act as a traumatic factor. The invasive nature of the diffuse PVNS form, with destruction of the joint cartilage and bone is well documented, some believe that a similar infiltrating process as the one observed in the pannus of rheumatoid arthritis can occur.

The diagnosis is suspected clinically and confirmed by the radiological and anatomopathologic examinations. The clinical findings are not specific, the patient could be oligosymptomatic, as in the present case, and even present intermittent pain, progressive edema of the involved joint, limitation of movement and articular blockage. The definitive diagnosis can be retarded for years, after the appearance of the symptoms and clinical signs. The difficulty of the clinical diagnosis is due to its rarity and to the fact of simulating mechanical originated lesions (meniscal lesions, intra-articular free bodies etc.), or even synovial sarcoma, mainly when the affected joint is the knee. Given the difficulties of obtaining a conclusive PVNS clinical and radiographic diagnosis, other complementary imaging tests are essential for the diagnosis and planning of the appropriate treatment. ${ }^{36}$

Histologically, these lesions present synovial hyperplasia, hypervascularization, accumulation of histiocytes and extracellular deposition of hemosiderin. The presence of intra and extracellular hemosiderin shows in the macroscopy reddish or chocolate like color, hence the name pigmented. The following criteria are important in this evaluation: hypercellularity, infiltrated linfoplasmocitary, presence of multinucleate giant cells, phagocytes containing hemosiderotic pigment. The hypercellularity sometimes accompanied by mitosis can lead equivocally to the diagnosis of malignant neoplasia, a synovial sarcoma. Giant multinuclear cells, however, generally do not occur in synovial sarcoma besides the absence of phagocytes with hemosiderin pigment. Rheumatoid arthritis, synovial hemangioma and hemophilic arthritis can also produce synovial thickening, hemorrhage and hemosiderin deposit, which are very similar to the findings in PVNS. ${ }^{36}$

The radiological findings of PVNS are joint effusion and cystic erosion of the bone in $50 \%$ of the patients. The magnetic resonance imaging (MRI) is the test that better differentiates synovial pathologies and can make an early diagnosis. ${ }^{37-40}$ Characteristic findings in the MRI are areas of low signal in the pondered sequences in $\mathrm{T} 1$ and $\mathrm{T} 2$, which correspond to a deposit of hemosiderin inside the synovia and are characteristic. The localized nodular aspect of PVNS is typical. The lesion is highlighted after contrast, delimiting its extension for later synovectomy. The evaluation of the extension of the bone involvement by MR is also important. This patient did not present this classic PVNS image, but a progressive synovitis that demanded other differential diagnosis.

The differential diagnosis of PVNS should be done with disorders that presents with joint effusion and synovial thickening, for example, rheumatoid arthritis and tuberculosis, diseases that have characteristics of systemic involvement and do not compromise exclusively the synovia and other components of the articulation. The MRI is important to differentiate some diseases which basically compromise the joint and neighboring structures like synovial hemangioma, synovial osteochondromatosis, synovial arborescence lipoma and synovial sarcoma. ${ }^{36}$ Thus, PVNS presents a typically in all the imaging sequences a low signal intensity (created by paramagnetic effects of hemosiderin deposits and fibrous tissue). The low signal blooming effect of hemosiderin is best seen on T2-weighted gradient-echo images, besides presenting strong uptake of the endovenous contrast. The synovial hemangioma is a benign vascular tumor that usually extends outside the articulation; It is hypotense in T1 with punctuated images of linear 
high-intensity signal, corresponding to the fibroadipose septum between the vascular channels. The T2-weighted images demostrates hypersignal and the septa are hypointense. In the synovial osteochondromatosis in the T1- weighted images, it is verified a low to intermediate intensity of the signal inside the synovial membrane and joint space, while in $\mathrm{T} 2$ the intensity of the signal is variable, due to the cartilaginous nature of the lesion and the extension of the calcified areas. In this disorder are observed ossified nodules, which can develop adipose marrow with the same intensity of signal of the arborescent lipoma. However, the simple RX allows the distinction between the two entities, by showing, in the first, multiple calcified bodies or ossificated inside the joint space. The synovial lipoma is an isolated intra-articular mass, has intensity of signal similar to that of fat in all the sequences, just like the arborescent lipoma, but can distinguish itself by its round shaped or oval form and by the absence of synovial proliferation. Arborescent lipoma is a rare intra-articular disease of unknown etiology, which consists of diffuse fat infiltration in the synovial membrane. The lipomatous fatty content of the lesion is well characterized in MRI or in the Computed Tomography. The synovial sarcoma presents extra-articular extension, calcification and bone invasion, aspects not found in PVNS. ${ }^{36-39}$

Treatment consists in synovectomy with very good results and little recurrence in the nodular form. In contrast, the diffuse form can have high recurrence rates. Patients not adequately treated can evolve to articular destruction and arthroplasty may be the solution in these cases. ${ }^{41-45}$

This patient had an excellent response to synovectomy, as demonstrated in the MRI performed nine months later.

\section{REFERÊNCIAS BIBLIOGRÁFICAS}

\section{REFERENCES}

1. Liphaus BL, Campos LMMA, Silva CAA, Kiss MHB. Manifestações osteoarticulares nas doenças não reumatológicas. Pediatria (São Paulo) 2001;23(2): 168-78.

2. Adelani MA, Wupperman RM, Holt GE. Benign synovial disorders. J Am Acad Orthop Surg 2008;16(5):268-75.

3. Mohana-Borges AV, Chung CB, Resnick D. Monoarticular arthritis. Radiol Clin North Am 2004;42(1):135-49.

4. Chassaignac M. Cancer de la gaine des tendons. Gaz Hosp Civ Milit 1852;47:185-6.

5. Simon G. Extirpation einer sehr grossen, mit dickem stiele angewachsenen kniegelenkmaus mit glucklichem erfolge. Arch Klinn Chir 1864;6: 573-6.

6. Jaffe HL, Lichtenstein L, Sutro CJ. Pigmented vilonodular synovitis, bursitis and tenosynovitis. A discussion of the synovial and bursal equivalents of the tenosynovial lesion commonly denoted as xanthoma, xanthogranuloma, giant cell tumor or myeloplaxoma of the tendon sheath, with some consideration of this tendon sheath lesion itself. Arch Pathol 1941;31:731-65.

7. Moser E. Primares sarkom der fussgelenklapsel. Extirpation. Dauerheilung Dtsch Z Chir 1909;98:306-10.

8. Granowitz SP, D'Antonio J, Mankin HL. The pathogenesis and long-term end results of pigmented villonodular synovitis. Clin Orthop 1976;114:335-51.

9. Ushijima M, Hashimoto H, Tsuneyoshi M, Enjoji M. Pigmented vilonodular synovitis. A clinicopathologic study of 52 cases. Acta Pathol Jpn 1986;36(3):317-26.

10. Bravo SM, Winalski CS, Weissman BN. Pigmented villonodular synovitis. Radiol Clin North Am 1996;34(2):311-26.

11. Rydholm U. Pigmented villonodular synovitis. Acta Orthop Scand 1998;69(2):203-10.

12. deVisser E, Veth RP, Pruszczynski M, Wobbes T, Van de Putte LB. Diffuse and localized pigmented villonodular synovitis: evaluation of treatment of 38 patients. Arch Orthop Trauma Surg 1999;119(78):401-4.

13. Durr HR, Stäbler A, Maier M, Refior HJ. Pigmented villonodular synovitis. Review of 20 cases. J Rheumatol 2001;28(7):1620-30.

14. Al-Nakshabandi NA, Ryan AG, Choudur H, Torreggiani W, Nicoloau $\mathrm{S}$, Munk PL, et al. Pigmented villonodular synovitis. Clin Radiol 2004;59(5):414-20.

15. Bouali H, Deppert EJ, Leventhal LJ, Reeves B, Pope T. Pigmented villonodular synovitis: a disease in evolution. J Rheumatol 31(8): 1659-62, 2004.

16. Ofluoglu O. Pigmented villonodular synovitis. Orthop Clin North Am 2006;37(1):23-33.

17. Tyler WK, Vidal AF, Williams RJ, Healey JH. Pigmented vilonodular synovitis. J Am Acad Orthop Surg 2006;14(6):376-85.

18. Neubauer P, Weber AK, Miller NH, McCarthy EF. Pigmented vilonodular synovitis in children: a report of six cases and review of the literature. Iowa Orthop J 2007;27:90-4.

19. Garner HW, Ortiguera CJ, Nakhleh RE. Pigmented villonodular synovitis. Radiographics 2008;28(5):1519-23.

20. Levin EJ, Gannon W. Diffuse villonodular synovitis of the shoulder. Am J Roentgenol Radium Ther Nucl Med 1963;89:1302-4.

21. Dorwart RH, Genant HK, Johnston WH, Morris JM. Pigmented villonodular synovitis of the shoulder: radiologic-pathologic assessment. Am J Roentgenol 1984;143(4):886-8.

22. Ganel A, Pritsch M, Yaffe B, Engelberg S, Apter S. Villonodular synovitis of the shoulder in the elderly. J Am Geriatr Soc 1987;35(7):692-5.

23. Flandry F, Norwood LA. Pigmented villonodular synovitis of the shoulder. Orthopedics 1989;12(5):715-8.

24. Sher M, Lorigan JG, Ayala AG, Libshitz HI. Case report 578: Pigmented villonodular synovitis of the shoulder. Skeletal Radiol 1990;19(2):131-3.

25. France MP, Gupta SK. Nonhemophilic hemosiderotic synovitis of the shoulder. A case report. Clin Orthop Relat Res 1991;262:132-6.

26. Graf J, Bernd L, Pauschert R, Niethard FU. Rare occurrence of villonodular synovitis of both shoulder joints. Z Rheumatol 1991;50(1):46-8.

27. Mulier T, Victor J, Van Den Bergh J, Fabry G. Diffuse pigmented villonodular synovitis of the shoulder. A case report \& review of literature. Acta Orthop Belg 1992;58(1):93-6. 
28. Dkhissi M, Aboutaib R, Zryouil B. Villonodular synovitis of the shoulder. A propos of a case report. Acta Orthop Belg 1992;58(2):213-5.

29. Tong KM, Hsu KC, Lee TS, Chang SM. Diffuse pigmented vilonodular synovitis of the shoulder: a case report. Zhonghua Yi Xue Za Zhi (Taipei) 1994;53(3): 188-92.

30. Cotten A, Flipo RM, Mestdahg H, Chastanet P. Diffuse pigmented villonodular synovitis of the shoulder.Skeletal Radiol 1995;24(4):311-3.

31. Cheng JC, Wolf EM, Chapman JE, Johnston JO. Pigmented villonodular synovitis of the shoulder after anterior capsulolabral reconstruction. Arthroscopy 1997;13(2):257-61.

32. Rutten MJ, van den Berg JC, van den Hoogen FH, Lemmens JA. Nontuberculous mycobacterial bursitis and arthritis of the shoulder. Skeletal Radiol 1998;27(1):33-5.

33. Muller LP, Bitzer M, Wahl W, Kriegsmann J, Junginger T. Pigmented villonodular synovitis of the shoulder joint. Zentralbl Chir 1998;123(11):1288-91.

34. Muller LP, Bitzer M, Degreif J, Rommens PM. Pigmented villonodular synovitis of the shoulder: review and case report. Knee Surg Sports Traumatol Arthrosc 1999;7(4):249-56.

35. Wirbel RJ, Braun C, Blandfort R, Pahl S, Mutschler WE. Villonodular synovitis of the shoulder. Orthopedics 2000;23(7):731-3.

36. Goldman AB, DiCarlo EF. Pigmented villonodular synovitis. Diagnosis and differential diagnosis. Radiol Clin North Am 1988;26(6):1327-47.
37. Hughes TH, Sartoris DJ, Schweitzer ME, Resnick DL. Pigmented villonodular synovitis: MRI characteristics. Skeletal Radiol. 1995;24(1):7-12.

38. Masih S, Antebi A. Imaging of pigmented villonodular synovitis. Semin Musculoskelet Radiol 2003;7(3):205-16.

39. Papp DF, Khanna AJ, McCarthy EF, Carrino JA, Farber AJ, Frassica FJ. Magnetic resonance imaging of soft-tissue tumors: determinate and indeterminate lesions. J Bone Joint Surg Am 2007;89(3):103-15.

40. Murphey MD, Rhee JH, Lewis RB, Fanburg-Smith JC, Flemming DJ, Walker EA. Pigmented villonodular synovitis: radiologicpathologic correlation. Radiographics 2008;28(5):1493-518.

41. Chiari C, Pirich C, Brannath W, Kotz R, Trieb K. What affects the recurrence and clinical outcome of pigmented villonodular synovitis? Clin Orthop Relat Res 2006;450:172-8.

42. Mahieu X, Chaouat G, Blin JL, Frank A, Hardy P. Arthroscopic treatment of pigmented villonodular synovitis of the shoulder. Arthroscopy . 2001;17(1):81-7.

43. Toro FG, Paulos JA, Fuentes DL, Sancy KL. Total shoulder arthroplasty in pigmented villonodular synovitis: a case report . J Shoulder Elbow Surg 2002;11(2):188-90.

44. Bynum CK, Tasto J. Arthroscopic treatment of synovial disorders in the shoulder, elbow, and ankle. J Knee Surg 2002;15(1):57-9.

45. Chiffolot X, Ehlinger M, Bonnomet F, Kempf JF. Arthroscopic resection of pigmented villonodular synovitis pseudotumor of the shoulder: a case report with three year follow-up. Rev Chir Orthop Reparatrice Appar Mot 2005;91(5):470-5. 